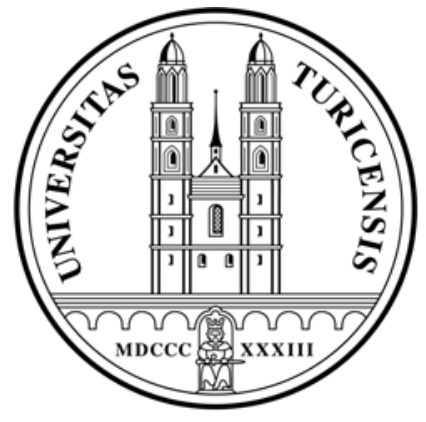

Institute for Empirical Research in Economics

University of Zurich

Working Paper Series

ISSN 1424-0459

Working Paper No. 339

Cashflow news, the value premium and an asset pricing view on European stock market integration

Thomas Nitschka

November 2007 


\title{
Cashflow news, the value premium and an asset pricing view on European stock market integration
}

\author{
Thomas Nitschka* \\ Institute for Empirical Research in Economics, University of Zurich
}

\begin{abstract}
The decomposition of national CAPM market betas of European countries' value and growth portfolio returns into cashflow and discount rate news driven components reveals that i) high average returns on value portfolios are associated with disproportionately high sensitivity to national cashflow news which corroborates recent evidence for the U.S. and ii) two-beta variants of national CAPMs capture the cross-sectional dispersion in European stock returns. The latter finding is suggestive of relatively well integrated stock markets among the core European countries and reflects basic asset pricing theory. One (national) discount factor should price any (international) asset.
\end{abstract}

JEL classification: G12, G14, G15

Keywords: cashflow beta, discount rate beta, CAPM, value premium

*E-mail: thomas.nitschka@iew.uzh.ch 


\section{Introduction}

If stock markets are perfectly integrated, then they should be driven by the same factors. Harvey (1991), Campbell and Hamao (1992) and Ferson and Harvey (1993) document the importance of global risk factors for the predictability of national stock market returns and explaining their cross-sectional differences. However, if capital markets are sufficiently integrated, then cross-sectional dispersion in international asset returns should be explained by national risk factors as well. It is this latter line of thought that this paper pursues. This argument follows immediately from the basic pricing equation for asset returns

$$
1=E_{t}\left(M_{t+1} R_{t+1}^{i}\right)
$$

with $M_{t+1}$ the stochastic discount factor and $R_{t+1}^{i}$ the gross return on asset or portfolio $i$. In words, an expected asset return should be constant once discounted with the stochastic discount factor (SDF) that is the same for all assets. Since equation (1) should hold for any asset from a national investor's point of view, it requires sufficiently integrated financial markets when confronted with foreign asset returns.

This paper focuses on the core European countries ${ }^{1}$ that experienced a convergence process in the course of the establishment of the European Monetary Union (EMU). Hence one could expect that these European stock markets are relatively well integrated. If this is the case, equation (1) should be applicable from each national investor's point of view to explain the cross-sectional dispersion in European stock returns. Indeed, the empirical evidence presented in this paper suggests that this reasoning is true. Of course, the empirical analysis conducted in this paper relies on the choice of the stochastic discount factor, i.e. the asset pricing model. I focus on the two-beta variant of the Sharpe (1964) and Lintner (1965) capital asset pricing model (CAPM), recently proposed by Campbell and Vuolteenaho (2004) to explain the value

\footnotetext{
${ }^{1}$ These countries are Belgium, France, Germany, Italy, the Netherlands, Spain and Switzerland, the only country that is not a member of but tightly linked with the EMU.
} 
premium on U.S. stock markets. Given this choice of the pricing kernel, it is natural to additionally examine the value premium in the European context.

Value stocks, defined as stocks with high book value relative to market value (B/M), high earnings-to-price ratio (E/P), high cashflow-to-price ratio $(\mathrm{C} / \mathrm{P})$ and high dividend-to-price ratio $(\mathrm{D} / \mathrm{P})$ receive a lot of attention by practitioners as well as academics since they offer higher average returns than expected from their market betas in a Sharpe and Lintner CAPM. Conversely, growth stocks (stocks with e.g. low book-to-market value ratio) promise lower returns than predicted by the CAPM. This finding is not a unique observation on U.S. stock markets but by now well documented in international data (e.g. Capaul et al., 1995; Chan et al.,1991; Fama and French, 1998).

The Sharpe-Lintner CAPM assumes the existence of a so called market portfolio comprising all risky assets. The excess return on this market portfolio is a measure of all systematic sources of risk. Differences in the sensitivity to the market return ("betas") should thus explain differences in average asset returns. In empirical work the market return is typically proxied by broad stock market indexes. While this practice can be criticized on various grounds (e.g. Roll, 1977; Campbell, 1996; Jagannathan and Wang, 1996; Lettau and Ludvigson, 2001a), Davis et al. (2000) show that the CAPM works well when confronted with U.S. value and growth stock data from the sample period from 1929 to 1963 but works poorly in the modern time period from 1963 to the present.

Campbell and Vuolteenaho (2004) explain the difference in the performance of the CAPM in the two sample periods by decomposing CAPM market betas into a cashflow ("bad") and discount rate ("good") variety. Intuitively, bad news about the market's future cashflows reflect a decrease of wealth and hence lead to a fall in the value of the market but leave future investment opportunities unaffected. The value of the market portfolio could also decline because investors increase the discount rate applied to cashflows, which at the same time 
mirrors better future investment opportunities. Furthermore, the intertemporal CAPM of Merton (1973) suggests that the receptiveness to innovations in dividends (cashflows) should be rewarded with a higher price of risk than sensitivity to discount rate news. Campbell and Vuolteenaho (2004) show that value stocks' market betas in U.S. post-war data contain a substantially higher cashflow component than growth stocks' market betas which explains seemingly abnormally high average returns on value portfolios.

This paper shows that European value stocks offer higher excess returns than their growth portfolio counterparts. In line with the findings of Campbell and Vuolteenaho (2004), Cohn et al. (2003) and Campbell et al. (2005), high average returns are associated with disproportionately high cashflow components in national market betas. Furthermore, from the perspective of a national investor, average returns on European value and growth portfolios can be reconciled with two-beta variants of national CAPMs. Hence, the implications of capital market integration on asset pricing theory seem to be reflected in the sample of European countries under consideration.

Interestingly, even though high average returns go hand in hand with high cashflow betas relative to discount rate betas, cross-sectional differences among returns on the European value and growth stocks seem to be explained by differences in national discount rate betas for five of the seven countries. The lower the sensitivity to better than expected discount rate news, i.e. "good" news, the higher is the average return. Differences in national cashflow betas explain cross-sectional dispersion in European stock returns from the perspective of a Belgium and Dutch investor.

I use European value and growth portfolios for the assessment of the explanatory power of national two-beta variants of the CAPM for the cross-section of European stock returns. But notice that it is not the aim of this paper to explain the cross-sectional dispersion of returns in the value versus growth domain. Rather the question is: Can we explain why e.g. the average return on the Belgium value portfolio is different from the German value portfolio from a 
Swiss investor's point of view? The sorting of stocks into portfolios according to book-tomarket ratios guarantees large spreads in average returns and thus facilitates the crosssectional analysis.

The countries taken into question in this paper (with the exception of Switzerland) experienced the establishment of the European monetary system with a period of monetary and fiscal policy convergence, interrupted by several currency crises in the 1990s and finally the launch of the European Monetary Union (EMU) in 1999. The empirical exercises conducted in this paper are thus an assessment of the integration of the core European stock markets in the sample period from the first quarter of 1975 to the fourth quarter of 2005.

From an asset pricing perspective, the choice of European countries is guided by two additional considerations. First, I would like to minimize the impact of exchange rate risk and focus on purely stock market based explanations of cross-sectional differences in stock returns. Various versions of international asset pricing models show that exchange rate risks are an important factor in explaining the cross-sectional dispersion in international stock market returns (e.g. Dumas and Solnik, 1995; Gerard and De Santis, 1997; Harvey, 1991; Solnik, 1974). Since this paper concentrates on the core EMU countries plus Switzerland, the impact of foreign exchange risks on cross-sectional stock returns is likely to be relatively small. Secondly, Lane and Milesi-Feretti (2005) show that European investors predominantly invest into euro-area equity. Thus the European value and growth portfolios should represent the investment opportunities of national investors in European countries.

The remainder of this paper is organized as follows. In section two, I sketch the framework of Campbell (1991) and Campbell and Vuolteenaho (2004) used to identify cashflow and discount rate betas. Thereafter, I briefly discuss the choice of state variables in section three and provide details of the data employed in this paper in section four. Section five discusses the empirical evidence. Finally, section six concludes. 


\section{Theoretical framework}

The identification of cash flow and discount rate news driven components in simple and excess stock returns is based on the relationship between prices, dividends and returns as formulated in the dividend ratio model of Campbell and Shiller (1988a).

A log-linear approximation of the stock return, $R_{t+1}$, gives

$$
r_{t+1} \approx k+\rho p_{t+1}+(1-\rho) d_{t+1}-p_{t}
$$

where $r_{t+1}$ is the $\log$ stock return, $p_{t}$ the $\log$ stock price at time $\mathrm{t}, d_{t+1} \log$ dividends, $k$ summarizes constant terms and $\rho=\frac{1}{1+\exp (d-p)}$, with $d-p$ the long-run mean of the log dividend-price ratio, is a weight obtained in the log-linearization. Rearranging (2) for the stock price, expanding to the infinite horizon and taking expectations on both sides of the equation yields

$$
p_{t}=\frac{k}{1-\rho}+E_{t}\left[\sum_{j=0}^{\infty} \rho^{j}\left((1-\rho) d_{t+1+j}-r_{t+1+j}\right)\right]
$$

Substituting (3) into (2), Campbell (1991) shows that unexpected changes in stock returns obey

$$
r_{t+1}-E_{t} r_{t+1}=\left(E_{t+1}-E_{t}\right) \sum_{j=0}^{\infty} \rho^{j} \Delta d_{t+1+j}-\left(E_{t+1}-E_{t}\right) \sum_{j=1}^{\infty} \rho^{j} \Delta r_{t+1+j}
$$

where $\Delta$ denotes the difference operator and $E_{t}$ rational expectations at time t. Revisions of expected future dividend growth are written as $\left(E_{t+1}-E_{t}\right) \sum_{j=0}^{\infty} \rho^{j} \Delta d_{t+1+j}$, changes of future discount rates as $\left(E_{t+1}-E_{t}\right) \sum_{j=1}^{\infty} \rho^{j} \Delta r_{t+1+j}$. 
Equation (4) states that unexpected changes of stock returns have to be associated with revisions of expectations of future cashflows or discount rates or both. Following Campbell (1991), equation (4) can be written in more compact notation as

$$
v_{r, t+1}=\eta_{C F, t+1}-\eta_{D R, t+1}
$$

with $v_{r, t+1} \equiv r_{t+1}-E_{t} r_{t+1}$ the unexpected component of the stock return, $\eta_{C F, t+1} \equiv\left(E_{t+1}-E_{t}\right) \sum_{j=0}^{\infty} \rho^{j} \Delta d_{t+1+j}$ representing news about dividend changes, i.e. cash flows and $\eta_{D R, t+1} \equiv\left(E_{t+1}-E_{t}\right) \sum_{j=1}^{\infty} \rho^{j} \Delta r_{t+1+j}$ which denotes news about returns, i.e. discount rates.

In order to identify cash flow and discount rate components in stock returns, Campbell (1991) suggests to use a first-order VAR of the form

$$
\boldsymbol{z}_{t+1}=\boldsymbol{\mu}+\boldsymbol{\Gamma} \boldsymbol{z}_{t}+\boldsymbol{u}_{t+1}
$$

where $\boldsymbol{z}_{t+1}$ is a k-by-1 state vector with the stock return, $\mathrm{r}_{\mathrm{t}+1}$, as first element and variables which predict stock returns, $\boldsymbol{\mu}$ is a k-by- 1 vector of constants and $\Gamma$ a k-by-k matrix of VAR parameters. Shocks are i.i.d. and represented by the k-by-1 vector $\boldsymbol{u}_{t+1}$. The assumption of a first-order VAR is not restrictive because a higher-order VAR can be written in first-order companion form (Campbell and Shiller, 1988a).

Since the state vector, $\boldsymbol{z}_{t+1}$, includes variables that predict stock returns, the discount rate news component is directly estimated in the VAR whereas the cash flow news component is a residual. It is that part of the return which is not explained by the state variables.

Under the assumption that the data is generated by (6), forecasts of future returns obey

$$
E_{t} r_{t+1+j}=\mathbf{e 1}^{\prime} \boldsymbol{\Gamma}^{j+1} \boldsymbol{z}_{t}
$$

with $\boldsymbol{e} \mathbf{1}$ a k-by-1 vector whose first element is one and all other elements zero. The discounted sum of changes in the expectation of future returns, i.e. the discount rate component of the return, can thus be written as 


$$
\begin{aligned}
\boldsymbol{\eta}_{D R, t+1} & \equiv\left(E_{t+1}-E_{t}\right) \sum_{j=1}^{\infty} \rho^{j} \Delta r_{t+1+j} \\
& =\mathbf{e}^{\prime} \sum_{j=1}^{\infty} \rho^{j} \boldsymbol{\Gamma}^{j} \boldsymbol{u}_{t+1} \\
& =\mathbf{e}^{\prime} \rho \boldsymbol{\Gamma}(\boldsymbol{I}-\rho \boldsymbol{\Gamma})^{-1} \boldsymbol{u}_{t+1}=\lambda^{\prime} \boldsymbol{u}_{t+1}
\end{aligned}
$$

with $\lambda^{\prime}=\boldsymbol{e} \mathbf{1}^{\prime} \rho \boldsymbol{I} \boldsymbol{I}-\rho \boldsymbol{\Gamma}^{-1}$. The cash flow news component is then given by

$$
\boldsymbol{\eta}_{C F, t+1}=\left(\mathbf{e} 1^{\prime}+\lambda^{\prime}\right) \boldsymbol{u}_{t+1}
$$

implied by equations (5) and (8) because $v_{\mathrm{r}, \mathrm{t}+1}$ can be picked out with $\boldsymbol{e} \mathbf{1}^{\prime} \boldsymbol{u}_{\mathrm{t}+1}$.

I report the receptiveness of value and growth stocks to cashflow news and discount rate news as cashflow ("bad") beta and discount rate ("good") beta. Intertemporal asset pricing theory suggests that the former type of risk should be associated with a higher risk premium than the latter one (Merton, 1973). Intuitively, bad news about the market's future cashflows reflect a decrease of wealth and hence lead to a fall in the value of the market but leave future investment opportunities unaffected. The value of the market portfolio could also decline because investors increase the discount rate applied to cashflows, which at the same time mirrors better future investment opportunities. Hence, receptiveness to discount rate news is less risky than sensitivity to cashflow news and therefore the terminology "bad" cashflow and "good" discount rate beta introduced by Campbell and Vuolteenaho (2004). The decomposition into cashflow and discount rate components could also be interpreted as decomposing the market return into its permanent and transitory parts according to Campbell and Vuolteenaho (2004). A stock price is the net present value of future discounted dividend growth. Hence a drop in dividend growth permanently affects the stock price and thus returns, whereas temporarily high discount rates could be offset by relatively low discount rates in the future. This interpretation underlies the assumption that dividend growth is unpredictable. However, appropriately defined macroeconomic variables do predict dividend growth in the long-run (Lettau and Ludvigson, 2005; Hoffmann, 2006), which leaves the impression that 
not all changes in dividends can be considered as permanent and hence this latter interpretation should be considered with caution. ${ }^{2}$

In order to obtain "bad” and “good” betas, I follow Campbell and Vuolteenaho (2004) and calculate cashflow betas from

$$
\beta_{i, C F}=\frac{\operatorname{cov}\left(r_{i, t}, \eta_{C F, t}\right)}{\operatorname{var}\left(r_{M, t}-E_{t} r_{M, t}\right)}
$$

Discount rate betas are obtained from

$$
\beta_{i, D R}=\frac{\operatorname{cov}\left(r_{i, t},-\eta_{D R, t}\right)}{\operatorname{var}\left(r_{M, t}-E_{t} r_{M, t}\right)}
$$

where cov and var denote sample covariances and variances respectively, $r_{\mathrm{i}, \mathrm{t}}$ is the log excess return on stock $i$ over the risk-free rate, $\eta_{\mathrm{CF}, \mathrm{t}}$, the estimated cashflow news term, $\eta_{\mathrm{DR}, \mathrm{t}}$,the estimated discount rate news component and $r_{\mathrm{M}, \mathrm{t}}-E_{\mathrm{t}} r_{\mathrm{M}, \mathrm{t}}$ the unexpected return on the market portfolio. The discount rate beta is here defined as the covariance of a stock return with lower than expected discount rates, i.e. "good" news. Note that these beta definitions differ from regression estimates. Betas are measured separately and conditioned on the variance of the unexpected market return not on the variance of the estimated news terms as would be the case in a regression. This definition implies that the sum of cashflow and discount rate betas equals the market beta, such that

$$
\beta_{i, M}=\beta_{i, C F}+\beta_{i, D R}
$$

\section{State variables: Predictors of international stock returns}

The success of the VAR in identifying cashflow and discount rate news components of a stock return relies on the choice of state variables which have to explain stock market returns. Cashflow, i.e. dividend, news components are obtained as a residual from the VAR. A major

\footnotetext{
${ }^{2}$ I thank Mathias Hoffmann for clarifying this point to me
} 
problem in applying this approach to international stock markets is to find a common set of predictive variables for national market returns.

Campbell and Hamao (1992) provide evidence that the U.S. dividend-price ratio and the U.S. relative t-bill rate predict Japanese stock returns. This finding is most pronounced for the 1980s and conveys the notion of a common, temporary component in national stock markets. Guo (2006) shows that short-run fluctuations of the ratio of consumption to aggregate wealth in the U.S. - cay - do not only predict time-varying excess returns on U.S., as shown by Lettau and Ludvigson (2001), but also on foreign stock markets with considerable success. Nitschka (2007) underscores formally that if the basic logic of the cointegration framework of Lettau and Ludvigson (2001) holds, then U.S. cay has to predict foreign stock returns. He exploits this finding to explain the comovement of the G7 stock markets at the business cycle frequency because the predictive power of U.S. cay peaks at three to four-year horizon and survives even in the presence of country-specific predictive variables. Hence, U.S. cay is a natural candidate as state variable to obtain cashflow and discount rate news driven components of international stock market returns.

Campbell and Vuolteenaho (2004) point out that the two-beta CAPM explanation for the U.S. value premium hinges on the use of the small-stock value spread, i.e. the difference in the logarithmic book-to-market value ratio on a small value portfolio and a small growth portfolio, as state variable in the market return decomposition into news components. Campbell and Vuolteenaho (2004) motivate the use of the small-stock value spread by the inability of the Sharpe-Lintner CAPM to explain returns on small value and growth portfolios, which reflects that the value spread inherits information about systematic sources of risk not captured by the CAPM. However, the use of the small stock value spread as predictive variable has not remained uncontroversial (Liu and Zhang, 2006), in particular because the value spread's forecast ability seems to occur only in conjunction with other predictive variables. 
To address this concern and encouraged by the main results of Campbell and Hamao (1992), Guo (2006) and Nitschka (2007), I run univariate regressions of the G7 market excess returns on the U.S. value spread for which results are presented in table 1. If the basic logic of a common, transitory component in national stock markets pertains, then the U.S. value spread is also a potential explanatory variable for foreign stock market returns.

Table 1 displays that the value spread explains excess returns on the G7 stock markets at rather short, one and four quarter, horizon for all of the G7. It thus seems to be the ideal complement to cay which performs best at the business cycle frequency. The predictive power of the value spread highlights again the importance of the common, transitory component in international stock markets even at short horizons and the international evidence supports the argumentation line of Campbell and Vuolteenaho (2004).

Ideally, country-specific predictors of stock returns should complement the U.S. value spread and U.S. cay as forecast variables. However, e.g. Nitschka (2007) shows that the forecast ability of a national financial variable as the dividend-price ratio varies across countries. Interest rate based predictors are not available for all of the countries under consideration because especially data on short-term interest rates is simply not available for the whole sample period from the first quarter of 1975 to the fourth quarter of 2005. More general, it is not clear if the same set of national variables exhibit predictive power for their national stock market returns at all as the literature on the predictive power of national consumption-wealth ratios for national stock market returns suggests. ${ }^{3}$

Because of these considerations, I push the idea of the common temporary component in stock markets to the extreme and use the U.S. price-earnings ratio as final stock market predictor for the European stock markets. The price-earnings ratio is defined as log of the

\footnotetext{
${ }^{3}$ Evidence by Fernandez-Corugedo et al. (2003), Fisher and Voss (2003), Tan and Voss (2004) and Ioannidis et al. (2006) suggests that short-run fluctuations in national consumption-wealth ratios predict national stock market returns . However, these studies focus on Anglo-Saxon countries while Hamburg et al. (2007) present evidence that German cay does not predict German stock market returns but macroeconomic variables as the unemployment rate. The predictive power of a Japanese consumption-wealth for national stock market returns is
} 
S\&P 500 stock index less a ten-year moving average of earnings on the S\&P 500 as in Campbell and Shiller (1988b, 1998). ${ }^{4}$ I also experimented with other U.S. variables that have been used as predictors of the U.S. stock market such as the relative treasury bill rate (Campbell, 1991; Hodrick, 1992), the rate of return on a 3-month treasury bill less a one-year backward moving average, as well as the term spread, the interest rate on a long-term U.S. government bond less the interest rate on a short-term note (Keim and Stambaugh,1986; Campbell, 1987; Fama and French, 1989). It turns out that the results only depend on the use of the value spread and cay. All the other variables can be employed interchangeably.

However, the price-earnings ratio predicts stock returns best at time horizons spanning several years (Campbell and Shiller, 1988b), such that this variable seems to be the ideal complement to the value spread (peak of forecast ability at one to four-quarters) and cay (predictive power peaks at three to four-year horizon), whereas interest rate based predictors seem to track the cyclical fluctuation in stock returns very much as cay does.

\section{$4 \quad$ Data}

Data on monthly and annual international value and growth returns is freely available on Kenneth French's website. ${ }^{5}$ Since I use cay as state variable, which is only observed at the quarterly frequency, I construct end-of-quarter return series from the monthly observations. Value and growth portfolios employed in this paper are book-to-market ratio sorted. The portfolios are formed at the end of December each year by sorting on their book-to-market value ratios and then value-weighted returns are calculated for the following 12 months. The value portfolios contain firms in the top 30 percent of a ratio and the growth portfolios contain firms in the bottom 30 percent. I use returns on value and growth portfolios of Belgium,

virtually zero as well (Nagayasu, 2006). U.S. cay, however, predicts returns on Anglo-Saxon and European stock markets (Guo, 2006; Nitschka, 2007).

${ }^{4}$ Data is freely available on Robert J. Shiller’s webpage http://www.econ.yale.edu/ shiller/data.htm 
France, Germany, Italy, The Netherlands, Spain and Switzerland to investigate the sensitivity of these returns with respect to cashflow and discount rate news on the respective market indexes. I employ the respective countries’ Morgan Stanley Capital International (MSCI) indices as national stock market indexes which can be freely downloaded from http://www.mscibarra.com.

All indexes and hence returns are expressed in local currency, i.e. if I examine the crosssection of all of the European value and growth stock returns from a German perspective, then all returns are denominated in Deutschmark/Euro. If I take the perspective of a Swiss investor, then all returns are in Swiss Francs, etc. Excess returns are obtained with local short-term interest rates or in cases where these interest rates are not available the German three-month call money market rate. These data are from the IFS CD November 2006. U.S. cay is publicly available on Martin Lettau's webpage http://pages.stern.nyu.edu/ mlettau/, the U.S. priceearnings ratio is defined as log of the S\&P 500 stock index less a 10-year moving average of log earnings on the S\&P 500 as in Campbell and Shiller (1988b, 1998). The small stock value spread is constructed as described in the appendix to Campbell and Vuolteenaho (2004). It is the difference in the logarithmic book-to-market value ratio on a small value portfolio and a small growth portfolio measured at June of each year for which data can be downloaded from Kenneth French's website as well. Intrayear values (from July to May) are obtained by adding the cumulative log return on the small-book-to-market portfolio to, and subtracting the cumulative log return on the high-book-to-market portfolio from, the end-of-June value spread. The sample period runs from the first quarter of 1975 to the fourth quarter of 2005.

\footnotetext{
${ }^{5}$ http://mba.tuck.dartmouth.edu/pages/faculty/ken.french/
} 


\section{Empirical Evidence}

This section is organized as follows. In the first subsection, I provide descriptive statistics that stress the presence of a premium on European value stocks. The second subsection gives details of the VAR characteristics when the Belgium, Dutch, German, French, Italian, Spanish and Swiss market returns are decomposed into cashflow and discount rate components. Then I assess the sensitivity of value and growth portfolio returns of the seven countries in question with respect to each of the estimated national market return's news components. Finally, this section examines the international cross-sectional dispersion in the value and growth portfolios to show that two-beta variants of national CAPMs explain average returns across European stock markets as suggested by basic asset pricing theory under the assumption of sufficiently integrated stock markets.

\subsection{Descriptive statistics}

Table 2 presents the annualized mean excess returns on the European value and growth portfolios from the perspective of a German investor. ${ }^{6}$ Hence all returns are denominated in Deutschmark and Euro since 1999Q1. The German three-month call money market rate is used to obtain excess returns. When focusing on the mean excess returns, there is strong evidence for the value premium on these European stock markets.

The only exception is Italy for which the growth portfolio promises a higher risk premium than the value portfolio. However, the sharpe ratios provide a less clear cut picture. In only four of the seven cases the sharpe ratio of the value portfolios is higher than that of the growth portfolio returns since the latter ones are less variable than the former ones.

\footnotetext{
${ }^{6}$ The mean returns, their standard deviations and the corresponding sharpe-ratios provide the same picture qualitatively when denominated in one of the other currencies.
} 


\subsection{VAR estimates}

Table 3, panel A presents OLS coefficient estimates of a VAR consisting of the return on the German market portfolio, the small stock value spread, vs, short-term fluctuations in the U.S. consumption-wealth ratio, cay, and the U.S. logarithmic price-earnings ratio, $p-e$. A lag length of one quarter is suggested by Akaike, Schwartz and Hannan-Quinn information criteria. Each row of Panel A corresponds to one equation estimated in the VAR. T-statistics are displayed in parenthesis below the VAR estimates. $\mathrm{R}^{2}$ denotes the adjusted $\mathrm{R}^{2}$. All VAR estimates rely to some extent on the parameter $\rho$ which should obey $\rho=\frac{1}{1+\exp (d-p)}$. I use sample means of the dividend yield to estimate $\rho$ for each of the stock markets under consideration. All of the results remain qualitatively unaltered if I follow Campbell and Vuolteenaho (2004) who use an annual value of $\rho=0.95$ and employ $\rho=0.95^{1 / 4}$, since I deal with quarterly data, or if I let $\rho$ vary around values between 0.9 and 0.99 .

I discuss the results for Germany because they are very much representative for all of the other countries. Thus I take the freedom to present only the market return equations of the other VARs in table 4. Focusing on the return equation in the first row, the state variables predict about four percent of the variation in the one-quarter excess return on the German market portfolio.

The value spread is marginally insignificant while U.S. cay marginally significantly explains the German market return at the 95 percent confidence level. This finding is noteworthy, as Hamburg at al. (2007) find the German consumption-wealth ratio to predict macroeconomic variables such as the unemployment rate rather than German stock market returns. Interestingly, the coefficient of the price-earnings-ratio is incorrectly signed and not statistically distinguishable from zero.

Panel B gives the share of the variance of the unexpected market return explained by cashflow and discount rate news respectively as well as the share captured by the covariance between 
the two news series. The cashflow news component clearly dominates variation in the German market return. This result is in stark contrast to the findings of Campbell (1991) and Campbell and Vuolteenaho (2004) that discount rate news predominantly cause variation in the U.S. market return in post-war data. However, the news terms are almost uncorrelated with each other. The correlation coefficient between the news series is about 0.23 .

Table 4 presents the return equation from the VARs of the other six countries. The results are qualitatively similar to the VAR characteristics obtained for the German market return. Furthermore, the correlation between the news series varies between -0.12 for Italy and Spain and 0.22 for Belgium and Switzerland.

\subsection{Bad and good betas}

Cashflow and discount rate news components of the German and the other countries' market portfolio are almost uncorrelated with each other. This observation conveys the notion that different types of stocks could react differently to cashflow and discount rate news. Furthermore, intertemporal asset pricing theory suggests that receptiveness to the market portfolio's cashflow news should be compensated with a higher risk premium than sensitivity to discount rate news (Merton, 1973). For the U.S., Campbell and Vuolteenaho (2004), Cohn et al. (2003) and Campbell et al. (2005) show that value stocks promise higher returns than growth stocks because their Sharpe-Lintner CAPM market betas are dominated by the cashflow variety whereas growth stocks' market betas are primarily driven by discount rate news.

Table 5 presents bad and good betas of value and growth portfolios of the seven European countries under consideration with respect to the news series obtained for the German market return. Again, I focus on Germany because the bad and good beta estimates of the other countries basically provide the same message. 
The picture that emerges from the results shown in table 5 is that high returns on value portfolios are associated with relatively high cashflow betas from the perspective of a German investor. Notice that the definitions of the betas imply that their sum should equal the corresponding market beta. Then the market betas of most of the value portfolio returns are higher than the growth portfolio market betas anyway. But this finding is caused by their high cashflow betas compared to growth portfolios.

The only exceptions are the German value and growth portfolios which mirror a salient feature of the data: The market betas of national growth stocks are higher than their value stocks' counterparts. However, the cashflow news driven component in value stocks' market betas is substantially higher than in the market beta of growth stocks. Hence, the evidence provided in table 5 corroborates Campbell and Vuolteenaho (2004), Cohn et al. (2003) and Campbell et al. (2005) in European data. High bad betas relative to discount rate betas are associated with relatively high average returns.

This conclusion is stressed by figures 1 to 7 . These figures display mean excess returns on the European national value and growth portfolios denominated in the respective local currency on the horizontal axis compared to the ratio of their cashflow beta, obtained for each of the seven market return news components, with the respective market betas on the vertical axis.

The relationship between average returns and the size of the cashflow component in the market beta is positive. The figures thus provide a visual impression of the conclusion drawn before.

\section{[ about here: Figures 1 to 7: Average excess returns on value and growth portfolios relative to the ratio of cashflow to respective market beta ]}




\subsection{The international cross-section of returns}

The focus of this subsection is closely related to the implications of the basic pricing equation (1) and the observation in table 1 that returns on value and growth portfolios vary internationally. The basic pricing equation states that one (national) discount factor should be applicable to price any (international) asset. Hence, international differences in stock returns should be captured by a national asset pricing model. So, the question addressed in this section is basically: Does the national two-beta CAPM provide a rationale for differences in average stock returns across countries? The focus is thus more on the international crosssectional dimension of stock returns than on the distinction between value and growth stocks, although the sorting of stocks with respect to their book-to-market ratios ensures large spreads in the European stock returns and is hence also important in this context.

The cross-sectional implication of the basic pricing equation can be seen by a simple rearrangement of equation (1), exploiting that $E(X Y)=E(X) E(Y)+\operatorname{cov}(X, Y)$ which gives

$$
E_{t}\left(R_{t+1}^{i}\right)=\frac{1}{E_{t}\left(M_{t+1}\right)}+\left(\frac{\operatorname{cov}\left(R_{t+1}^{i}, M_{t+1}\right)}{\operatorname{var}\left(M_{t+1}\right)}\right)\left(-\frac{\operatorname{var}\left(M_{t+1}\right)}{E_{t}\left(M_{t+1}\right)}\right)
$$

which can be summarized to

$$
E_{t}\left(R_{t+1}^{i}\right)-R_{t}^{f}=\beta_{M}^{i} \lambda_{M}
$$

with $R_{t}^{f}=\frac{1}{E_{t}\left(M_{t+1}\right)}$, the risk-free rate, $\beta_{M}^{i}=\frac{\operatorname{cov}\left(R_{t+1}^{i}, M_{t+1}\right)}{\operatorname{var}\left(M_{t+1}\right)}$, the regression coefficient of excess return $i$ on the discount factor, representing the asset-specific quantity of systematic risk, and $\lambda_{M}=-\frac{\operatorname{var}\left(M_{t+1}\right)}{E_{t}\left(M_{t+1}\right)}$ interpreted as the price of risk.

As the excess return on the market portfolio is the only source of systematic risk in a Sharpe (1964) and Lintner (1965) CAPM, (14) collapses to

$$
E_{t}\left(R_{t+1}^{i}\right)-R_{t}^{f}=\hat{\beta}_{R^{M}}^{i} \lambda_{R^{M}}
$$


in which $\lambda_{R^{M}}$ is the price of the market risk and $\hat{\beta}_{R^{M}}^{i}$ is the estimated asset-specific exposure to the market portfolio. High excess returns should thus be associated with high market betas as $\lambda_{R^{M}}$ is the same for all assets.

In the case of the two-beta CAPM, the cross-sectional regression (15) looks as follows

$$
E_{t}\left(R_{t+1}^{i}\right)-R_{t}^{f}=\hat{\beta}_{C F}^{i} \lambda_{C F}+\hat{\beta}_{D R}^{i} \lambda_{D R}
$$

where the betas represent the sensitivity of the stock excess returns on the cashflow and discount rate news terms of the respective market returns as given in table 3 for Germany. The pure market return betas for the simple CAPM are obtained from time series regressions of the value and growth stock returns on the respective market excess returns.

I follow Fama and MacBeth (1973) and estimate a cross-sectional regression of the value and growth portfolio returns on the estimated betas at each point in time. The risk prices are then averages of the estimated risk price series.

The cross-sectional results for the Sharpe (1964) and Lintner (1965) CAPM are given in table 6 with Shanken (1992) corrected t-statistics in parenthesis since the betas are generated regressors. $R^{2}$ is the cross-sectional $R^{2}$. Mean absolute pricing errors (mape) and mean squared pricing errors (mspe) are given in percentage points per quarter.

The results displayed in table 6 leave the impression that national CAPMs perform poorly in explaining international cross-sectional differences in stock returns. The only exception is Belgium for which the CAPM works fairly well. However, for the remaining countries the national CAPMs capture virtually none on the cross-sectional dispersion in European value and growth portfolios returns.

This picture dramatically changes once we consider the market return's cashflow and discount rate risk separately. Table 7 presents the cross-sectional regression estimates from the twobeta variants of the CAPM. 
The fit of this model is by far better and produces statistically significant risk prices. The $R^{2}$ statistics range from 0.28 for Italy to 0.66 for Spain. Moreover, mean squared and mean absolute pricing errors are substantially lower when compared with the ones obtained from the Sharpe-Lintner CAPMs. Thus the distinction between the market's cashflow and discount rate risks considerably improves the performance of the CAPM.

For five of the seven countries, differences in national discount rate betas account for the cross-sectional dispersion in European stock returns. The negative risk prices simply reflect the fact that discount rates are defined as better news about discount rates than expected. Hence there is a negative relation between average returns and discount rate betas for the respective countries. Figure 8 shows this relationship for Germany.

\section{[about here: Figure 8: Average returns vs. German discount rate betas]}

The higher the mean excess return (horizontal axis), the lower the beta to good news about the German stock market return (vertical axis). This picture is quite different when we regard the Netherlands. From the perspective of a Dutch investor differences in the sensitivity to the Dutch market's cashflow news explain international differences in stock returns. Figure 9 displays the positive relation between Dutch cashflow betas (vertical axis) and average returns on the European value and growth portfolios (horizontal axis). High average returns are hence the outcome of relatively high cashflow betas from the perception of a Dutch investor.

\section{[about here: Figure 9: Average returns vs. Dutch cashflow betas]}

It is interesting that there are fundamental differences in the systematic sources of risk that explain average returns from a national investor's perspective. Remember that discount rate news are directly estimated in the VAR. Hence, all of the information about stock market 
returns inherited in the state variables is shifted to the discount rate components. The state variables are motivated under the assumption that their predictive power is the mirror image of a common, temporary component in national stock markets. The very fact that the spreads in discount rate betas of the German, French, Italian, Spanish and Swiss market return help to explain the cross-sectional differences between the European value and growth portfolio returns suggests that these national investors regard differences in the sensitivity to the common stock market component as the decisive feature in order to judge the riskiness of stock returns. The residual information, i.e. cashflow news, plays a negligible role for these investors.

For a Benelux investor, the opposite reasoning seems to apply. Receptiveness to national market's cashflow news capture cross-sectional differences in average returns.

\section{Conclusions}

Employing the framework of Campbell (1991) and Campbell and Vuolteenaho (2004), I show that high average returns on European value portfolio returns can be reconciled with the twobeta variant of the Sharpe-Lintner CAPM from a national investor's perspective. High returns on value stocks are associated with relatively high cashflow betas compared to the respective discount rate betas. This finding is a salient feature of the data irrespective if one takes the stance of a Belgium, French, German, Italian, Dutch, Spanish or Swiss investor. It corroborates Campbell and Vuolteenaho (2004), Cohen et al. (2003) and Campbell at el. (2005) with regard to book-to-market ratio and size sorted portfolios in the U.S. In addition, two-beta versions of national CAPMs capture the cross-sectional dispersion in European value and growth stock returns. This paper thus provides empirical evidence for the implication that a national asset pricing model should explain cross-sectional dispersion in 
any asset as suggested by basic asset pricing theory if national capital markets are sufficiently integrated. 


\section{Acknowledgements}

Former versions of this paper circulated under the title "Does cashflow news explain the value premium on European stock market?”. This paper builds upon chapter two of my Ph.D. thesis entitled “An asset pricing view on international financial integration”. I would like to thank my supervisor Mathias Hoffmann for helpful remarks and suggestions. This research also benefited from comments by my discussants Florian Kajuth and Bernard Dumas as well as participants in the SMYE 2006 and the $6^{\text {th }}$ SFI Doctoral Workshop. Moreover, I gratefully acknowledge that data on international value and growth portfolio returns is published on Kenneth French's website as well as data on cay on Martin Lettau's website. Substantial parts of the research conducted in this paper are funded by the Deutsche Forschungsgemeinschaft through SFB 475, project B6: International Allocation of Risk. Any errors and omissions are my own. 


\section{References}

Campbell, J.Y., 1987. Stock Returns and the Term Structure. Journal of Financial Economics 18, 373-399.

Campbell, J.Y., 1991. A Variance Decomposition for Stock Returns. Economic Journal 101, 157-179.

Campbell, J.Y.,1996. Understanding Risk and Return. Journal of Political Economy 107, 298345.

Campbell, J.Y., Hamao, Y.,1992. Predictable Stock Returns in the United States and Japan: A Study of Long-Term Capital Market Integration. Journal of Finance 47, 43-69.

Campbell, J.Y., Polk, C., Vuolteenaho,T.,2005. Growth or Glamour? Fundamentals and Systematic Risk in Stock Returns. NBER working paper 11385.

Campbell, J.Y., Shiller, R.J., 1988a. The Dividend Price Ratio and Expectation of Future Dividends and Discount Factors. Review of Financial Studies 1, 195-227.

Campbell, J.Y., Shiller, R.J., 1988b. Stock Prices, Earnings, and Expected Dividends. Journal of Finance 43, 661-676.

Campbell, J.Y., Shiller, R.J., 1998. Valuation Ratios and the Long-Run Stock Market Outlook, Journal of Portfolio Management 24, 11-26.

Campbell, J.Y., Vuolteenaho, T., 2004. Bad Beta, Good Beta. American Economic Review 94, 1249-1275.

Capaul, C., Rowleya, I., Sharpe, W.F., 1993. International value and growth stock returns. Financial Analysts Journal, 27-36.

Chan, L.K.C., Hamao, Y., Lakonishok, J., 1991. Fundamentals and stock returns in Japan. Journal of Finance 46, 1739-1789.

Cohen, R.B., Polk, C., Vuolteenaho,T., 2003. The Price Is (Almost) Right, NBER working paper 10131.

Davis, J. L., Fama, E. F., French, K.R., 2000. Characteristics, Covariances and Average Returns: 1929 to 1997. Journal of Finance 55, 389-406.

de Santis, G., Gerard, B., 1997. International Asset Pricing and Portfolio Diversification with Time-Varying Risks. Journal of Finance 52, 1881-1912.

Dumas, B., Solnik, B., 1995. The World Price of Foreign Exchange Risk. Journal of Finance 50, 445-479.

Fama, E.F., French, K.R., 1989. Business Conditions and Expected Returns on Stocks and Bonds. Journal of Financial Economics 25, 23-49. 
Fama, E.F., French, K.R., 1998. Value versus Growth: The International Evidence. Journal of Finance 53, 1975-1999.

Fama, E.F., MacBeth, J.D., 1973. Risk, Return and Equilibrium: Empirical Tests. Journal of Political Economy 81, 607-631.

Fernandez-Corugedo, E., Price, S., Blake, A., 2003. The dynamics of consumer's expenditure: the UK consumption ECM redux. Bank of England working paper 204.

Ferson, W.E., Harvey, C.R., 1993. The Risk and Predictability of International Stock Returns. Review of Financial Studies 6, 527-566.

Fisher, L.A., Voss, G.M., 2004. Consumption, Wealth and Expected Stock Returns in Australia. Economic Record 80, 359-372.

Guo, H., 2006. The Risk-Return Relation in International Stock Markets. The Financial Review 41, 565-587.

Hamburg, B., Hoffmann, M., Keller, J., 2007. Consumption, Wealth and Business Cycles: Why is Germany different? forthcoming Empirical Economics

Harvey, C.R., 1991. The World Price of Covariance Risk, Journal of Finance 46, 111-157.

Hodrick, R.J., 1992. Dividend Yields and Expected Stock Returns: Alternative Procedures for Inference and Measurement. Review of Financial Studies 5, 357-386.

Hoffmann, M., 2006. Proprietary Income, Entrepreneurial Risk, and the Predictability of U.S. Stock Returns. mimeo University of Zurich.

Ioannidis, C., Peel, D.A., Matthews, K.P.G., 2006. Expected stock returns, aggregate consumption and wealth: some further evidence. Journal of Macroeconomics 28, 439-445.

Jagannathan, R., Wang, Z., 1996. The Conditional CCAPM and the Cross-Section of Expected Returns. Journal of Finance 51, 3-53.

Keim, D.B., Stambaugh, R.F., 1986. Predicting Returns in the Stock and Bond Markets. Journal of Financial Economics 17, 357-390.

Lane, P.R., Milesi-Ferretti,G.M., 2005. The International Equity Holdings of Euro Area Investors. IIIS discussion paper No. 104.

Lettau, M., Ludvigson, S., 2001. Consumption, Aggregate Wealth and Expected Stock Returns. Journal of Finance 56, 815-849.

Lettau, M., Ludvigson, S., 2005. Expected returns and expected dividend growth. Journal of Financial Economics 76, 583-626.

Lintner, J., 1965. The valuation of risk assets and the selection of risky investments in stock portfolios and capital budgets. Review of Economics and Statistics 47, $13-37$.

Liu, N., Zhang, L., 2006. Is the value spread a useful predictor of returns? NBER working paper 11326. 
Merton, R.C., 1973. An intertemporal capital asset pricing model. Econometrica 41, 867-887.

Nagayasu, J., 2006. Stocks, Consumption and Wealth: Some Evidence from the Tokyo Stock Exchange. Department of Social Sciences and Management Discussion paper No. 1154, University of Tsukuba.

Nitschka, T., 2007. International evidence for return predictability and its implications for the long-run covariation of the G7 stock markets. mimeo, University of Zurich.

Roll, R., 1977. A Critique of the Asset Pricing Theory's Tests: Part I: On Past and Potential Testability of the Theory. Journal of Financial Economics 4, 129-176.

Shanken, J., 1992. On the Estimation of Beta-Pricing Models. Review of Financial Studies 5, $1-33$.

Sharpe, W.F., 1964. Capital asset prices: A theory of market equilibrium under conditions of risk. Journal of Finance 19, 425-442.

Solnik, B., 1974. The international pricing of risk: An empirical investigation of world capital structure. Journal of Finance 29, 365-378.

Tan, A., Voss, G.M., 2003. Consumption and Wealth in Australia. Economic Record 79, 3956. 
Table 1: Long-horizon regressions of foreign stock market excess returns on U.S. small stock value spread (sample period 1969Q4 - 2005Q4)

\begin{tabular}{|c|c|c|c|c|c|c|c|}
\hline & $\mathrm{h}=1$ & $\mathrm{~h}=4$ & $\mathrm{~h}=8$ & $\mathrm{~h}=12$ & $\mathrm{~h}=16$ & $\mathrm{~h}=20$ & $\mathrm{~h}=24$ \\
\hline CND & $\begin{array}{c}-0.05 \\
(-0.87)\end{array}$ & $\underset{(-2.18)}{-0.33}$ & $\begin{array}{c}-0.33 \\
(-1.49)\end{array}$ & $\underset{(-1.78)}{-0.35}$ & $\underset{(-1.31)}{-0.24}$ & $\begin{array}{l}0.09 \\
(0.33)\end{array}$ & $\begin{array}{l}0.37 \\
(1.16)\end{array}$ \\
\hline $\mathrm{R}^{2}$ & 0.00 & 0.07 & 0.04 & 0.05 & 0.02 & 0.00 & 0.02 \\
\hline FRA & $\underset{(-2.36)}{-0.13}$ & $\underset{(-2.81)}{-0.45}$ & $\underset{(-2.19)}{-0.61}$ & $\begin{array}{c}-0.71 \\
(-1.70)\end{array}$ & $\begin{array}{c}-0.44 \\
(-0.77)\end{array}$ & $\begin{array}{l}0.17 \\
(0.24)\end{array}$ & $\begin{array}{l}0.72 \\
(1.02)\end{array}$ \\
\hline $\mathrm{R}^{2}$ & 0.02 & 0.09 & 0.08 & 0.08 & 0.01 & 0.00 & 0.00 \\
\hline GER & $\underset{(-2.01)}{-0.11}$ & $\begin{array}{c}-0.36 \\
(-1.89)\end{array}$ & $\underset{(-1.15)}{-0.41}$ & $\underset{(-0.80)}{-0.44}$ & $\underset{(-0.09)}{-0.06}$ & $\begin{array}{l}0.69 \\
(0.90)\end{array}$ & $\begin{array}{c}1.19 \\
(1.89)\end{array}$ \\
\hline $\mathrm{R}^{2}$ & 0.02 & 0.07 & 0.05 & 0.04 & 0.00 & 0.04 & 0.13 \\
\hline ITA & $\begin{array}{c}-0.10 \\
(-1.94)\end{array}$ & $\underset{(-2.54)}{-0.44}$ & $\begin{array}{c}-0.65 \\
(-1.75)\end{array}$ & $\begin{array}{c}-0.74 \\
(-1.71)\end{array}$ & $\begin{array}{c}-0.70 \\
(-1.68)\end{array}$ & $\begin{array}{c}-0.21 \\
(-0.41)\end{array}$ & $\begin{array}{l}0.22 \\
(0.31)\end{array}$ \\
\hline $\mathrm{R}^{2}$ & 0.01 & 0.06 & 0.06 & 0.05 & 0.03 & 0.00 & 0.00 \\
\hline JPN & $\underset{(-2.85)}{-0.16}$ & $\underset{(-2.36)}{-0.46}$ & $\underset{(-2.00)}{-0.74}$ & $\begin{array}{c}-0.90 \\
(-1.86)\end{array}$ & $\begin{array}{c}-0.99 \\
(-1.88)\end{array}$ & $\begin{array}{c}-0.84 \\
(-1.48)\end{array}$ & $\begin{array}{c}-0.65 \\
(-0.82)\end{array}$ \\
\hline $\mathrm{R}^{2}$ & 0.04 & 0.07 & 0.09 & 0.09 & 0.07 & 0.04 & 0.00 \\
\hline UK & $\begin{array}{c}-0.13 \\
(-3.07)\end{array}$ & -0.46 & $\begin{array}{c}-0.59 \\
(-3.10)\end{array}$ & $\begin{array}{c}-0.79 \\
(-3.11)\end{array}$ & $\underset{(-2.24)}{-0.68}$ & $\begin{array}{c}-0.40 \\
(-0.92)\end{array}$ & $\begin{array}{l}0.06 \\
(0.16)\end{array}$ \\
\hline $\mathrm{R}^{2}$ & 0.03 & 0.12 & 0.11 & 0.13 & 0.07 & 0.01 & 0.00 \\
\hline US & $\begin{array}{c}-0.08 \\
(-2.16)\end{array}$ & $\begin{array}{c}-0.32 \\
(-2.48)\end{array}$ & $\begin{array}{c}-0.34 \\
(-1.52)\end{array}$ & $\begin{array}{c}-0.43 \\
(-1.28)\end{array}$ & $\begin{array}{c}-0.27 \\
(-0.56)\end{array}$ & $\begin{array}{l}0.17 \\
(0.31)\end{array}$ & $\begin{array}{c}0.68 \\
(1.27)\end{array}$ \\
\hline $\mathrm{R}^{2}$ & 0.02 & 0.10 & 0.06 & 0.06 & 0.01 & 0.00 & 0.05 \\
\hline
\end{tabular}

Notes: This table displays OLS estimates from regressions of the form

$$
r_{t+h}^{i, e}=\alpha_{h}+\beta_{h} v s_{t}+\varepsilon_{t+h}
$$

with $r_{t+h}^{i, e}$ the log excess return on the MSCI stock index of country i at horizon $\mathrm{t}+\mathrm{h}$ and $v s_{t}$ is the U.S. small stock value spread. Newey-West (Newey and West, 1987) corrected t-statistics appear below the regressor estimates. $\mathrm{R}^{2}$ reports the adjusted $\mathrm{R}^{2}$. Bold faces highlight significant estimates. 
Table 2: Descriptive statistics (1975Q1 - 2005Q4)

\begin{tabular}{|c|c|c|c|}
\hline & $\begin{array}{c}\text { mean excess returns } \\
\text { (percentage points } \\
\text { p.a.) }\end{array}$ & $\begin{array}{c}\text { standard deviation } \\
\text { (percentage points } \\
\text { p.a.) }\end{array}$ & sharpe ratio \\
\hline Value Belgium & 13.08 & 50.22 & 0.26 \\
\hline Growth Belgium & 7.32 & 41.98 & 0.17 \\
\hline Value France & 11.04 & 59.56 & 0.19 \\
\hline Growth France & 5.57 & 47.64 & 0.12 \\
\hline Value Germany & 10.57 & 47.79 & 0.22 \\
\hline Growth Germany & 5.15 & 48.66 & 0.11 \\
\hline Value Italy & 3.50 & 66.70 & 0.05 \\
\hline Growth Italy & 5.35 & 58.30 & 0.09 \\
\hline Value Netherlands & 10.36 & 57.73 & 0.18 \\
\hline Growth Netherlands & 8.01 & 38.78 & 0.21 \\
\hline Value Spain & 4.38 & 65.97 & 0.07 \\
\hline Growth Spain & 2.31 & 64.94 & 0.04 \\
\hline Value Switzerland & 8.94 & 55.68 & 0.16 \\
\hline Growth Switzerland & 6.35 & 40.63 & 0.16 \\
\hline \multicolumn{4}{|c|}{$\begin{array}{l}\text { Notes: This table presents the annualized mean excess returns on value and growth portfolios of Belgium, } \\
\text { France, Germany, Italy, The Netherlands, Spain and Switzerland in percentage points per annum as well as the } \\
\text { respective standard deviation and sharpe ratio for the sample period 1975Q1 - 2005Q4. All returns are expressed } \\
\text { in Deutschmark and Euro after 1998Q4. The German 3-month call money market rate is used to obtain excess } \\
\text { returns. }\end{array}$} \\
\hline
\end{tabular}




\begin{tabular}{|c|c|c|c|c|c|}
\hline \multicolumn{6}{|c|}{ Panel A: VAR estimates } \\
\hline & $r_{t}^{M}$ & $v s_{t}$ & $c a y_{t}$ & $(p-e)_{t}$ & $R^{2}$ \\
\hline$r_{t+1}^{M}$ & $\frac{-0.07}{(-0.72)}$ & $\frac{-0.13}{(-1.83)}$ & $\begin{array}{l}2.56 \\
(1.97)\end{array}$ & $\begin{array}{l}0.05 \\
(1.50)\end{array}$ & 0.04 \\
\hline$v s_{t+1}$ & $\underset{(-1.53)}{-0.12}$ & $\begin{array}{l}\mathbf{0 . 7 7} \\
(13.13)\end{array}$ & $\begin{array}{l}0.52 \\
(0.47)\end{array}$ & $\underset{(2.18)}{\mathbf{0 . 0 7}}$ & 0.97 \\
\hline$c a y_{t+1}$ & $\frac{-0.02}{(-3.67)}$ & $\underset{(-0.88)}{-0.00}$ & $\begin{array}{l}\mathbf{0 . 6 6} \\
(9.23)\end{array}$ & $\underset{(-1.84)}{-0.00}$ & 0.83 \\
\hline$(p-e)_{t+1}$ & $\underset{(-1.02)}{-0.06}$ & $-\underset{(-1.44)}{0.06}$ & $\frac{1.18}{(1.48)}$ & $\begin{array}{c}0.96 \\
(17.46)\end{array}$ & 0.97 \\
\hline
\end{tabular}

Panel B: Variance share of news terms and correlation

$\begin{array}{lllll}\operatorname{var}_{N C F}: 0.95 & \operatorname{var}_{N D R}: 0.28 & -2 \operatorname{cov}\left(\eta_{D R}, \eta_{C F}\right): & \rho_{N C F, N D R}: & 0.23\end{array}$

$-0.23$

Notes: Panel A of this table displays the estimated VAR coefficients. Newey-West (Newey and West, 1987) corrected t-statistics appear in parenthesis below the estimates. The lag length of the VAR is one quarter. $r_{t+1}^{M}$ denotes the natural logarithm of the excess return on the German market portfolio, $v s_{t}$ is the U.S. small stock value spread, $c a y_{t+1}$ is the residual of the cointegrating relation between U.S. consumption and aggregate wealth, $(p-e)_{t}$ is the U.S. price-earnings ratio constructed as in Campbell and Shiller (1988b) . $R^{2}$ is the adjusted $R^{2}$

Panel B gives the shares of the market return variation explained by the variation in the two news series, $\operatorname{var}_{N C F}, \operatorname{var}_{N D R}$, and the covariance between the news components, $-2 \operatorname{cov}\left(\eta_{D R}, \eta_{C F}\right)$. It also presents the correlation coefficient between cashflow and discount rate components of the German market return, $\rho_{N C F, N D R}$. Bold faces highlight significant estimates. 


\begin{tabular}{|c|c|c|c|c|c|}
\hline \multicolumn{6}{|c|}{ Belgium } \\
\hline & $r_{t}^{M}$ & $v s_{t}$ & $\operatorname{cay}_{t}$ & $(p-e)_{t}$ & $R^{2}$ \\
\hline$r_{t+1}^{M}$ & $\begin{array}{c}-0.17 \\
(-1.84)\end{array}$ & $\underset{(-2.08)}{-0.13}$ & $\begin{array}{l}1.37 \\
(1.35) \\
\end{array}$ & $\begin{array}{c}0.04 \\
(1.37) \\
\end{array}$ & 0.03 \\
\hline \multicolumn{6}{|c|}{ France } \\
\hline & $r_{t}^{M}$ & $v s_{t}$ & $c a y_{t}$ & $(p-e)_{t}$ & $R^{2}$ \\
\hline$r_{t+1}^{M}$ & $\underset{(-0.71)}{-0.07}$ & $\underset{(-1.83)}{-0.13}$ & $\begin{array}{l}2.22 \\
(1.75)\end{array}$ & $\begin{array}{l}0.05 \\
(1.36)\end{array}$ & 0.02 \\
\hline \multicolumn{6}{|c|}{ Italy } \\
\hline & $r_{t}^{M}$ & $v s_{t}$ & $\operatorname{cay}_{t}$ & $(p-e)_{t}$ & $R^{2}$ \\
\hline$r_{t+1}^{M}$ & $\begin{array}{c}-0.02 \\
(-0.19)\end{array}$ & $\begin{array}{c}-0.08 \\
(-1.01)\end{array}$ & $\begin{array}{r}1.90 \\
(1.32)\end{array}$ & $\begin{array}{l}0.04 \\
(0.91)\end{array}$ & 0.00 \\
\hline \multicolumn{6}{|c|}{ Netherlands } \\
\hline & $r_{t}^{M}$ & $v s_{t}$ & $c a y_{t}$ & $(p-e)_{t}$ & $R^{2}$ \\
\hline$r_{t+1}^{M}$ & $\begin{array}{c}-0.06 \\
(-0.63)\end{array}$ & $\begin{array}{c}-0.10 \\
(-1.68)\end{array}$ & $\begin{array}{l}1.37 \\
(1.50) \\
\end{array}$ & $\begin{array}{l}0.02 \\
(0.74) \\
\end{array}$ & 0.02 \\
\hline \multicolumn{6}{|c|}{ Spain } \\
\hline & $r_{t}^{M}$ & $v s_{t}$ & $\mathrm{cay}_{t}$ & $(p-e)_{t}$ & $R^{2}$ \\
\hline$r_{t+1}^{M}$ & $\begin{array}{c}-0.08 \\
(-0.84)\end{array}$ & $\begin{array}{c}-0.09 \\
(-1.16)\end{array}$ & $\begin{array}{c}1.58 \\
(1.11)\end{array}$ & $\begin{array}{c}0.04 \\
(1.04) \\
\end{array}$ & 0.00 \\
\hline \multicolumn{6}{|c|}{ Switzerland } \\
\hline & $r_{t}^{M}$ & $v s_{t}$ & $c a y_{t}$ & $(p-e)_{t}$ & $R^{2}$ \\
\hline$r_{t+1}^{M}$ & $\underset{(-1.20)}{-0.11}$ & $\underset{(-1.80)}{-0.10}$ & $\begin{array}{l}2.20 \\
(1.84)\end{array}$ & $\underset{(1.67)}{0.05}$ & 0.03 \\
\hline
\end{tabular}

Notes: This table presents the return equations from the VARs of Berlgium, France, Italy, the Netherlands, Spain and Switzerland to decompose the respective market excess returns into their cashflow and discount rate components. Further details are given in the notes to table 3 


\begin{tabular}{ccc} 
& $\beta_{C F}$ & $\beta_{D R}$ \\
\hline Value BEL & 0.49 & 0.05 \\
Growth BEL & 0.36 & 0.09 \\
\hline Value FRA & 0.62 & 0.10 \\
Growth FRA & 0.43 & 0.17 \\
\hline & & 0.08 \\
\hline Value GER & 0.77 & 0.21 \\
Growth GER & 0.69 & 0.10 \\
\hline & & 0.17 \\
\hline Value ITA & 0.60 & 0.11 \\
Growth ITA & 0.44 & 0.11 \\
\hline Value NL & & \\
Growth NL & 0.70 & 0.06 \\
\hline Value ESP & 0.39 & 0.16 \\
\hline Growth ESP & & 0.20 \\
\hline Value CH & 0.42 & 0.13 \\
\hline Growth CH & 0.41 &
\end{tabular}

Notes: This table presents cashflow and discount rate beta estimates of value and growth stocks of Austria, Belgium, France, Germany, Ireland, Italy, Netherlands, Spain, Switzerland and the United Kingdom conditional of cashflow and discount rate components of the excess return on the German market portfolio.

Betas are calculated from

Cashflow beta:

$$
\beta_{i, C F}=\frac{\operatorname{cov}\left(r_{i, t}, \eta_{C F}\right)}{\operatorname{var}\left(r_{M, t}-E_{t-1}\left(r_{M, t}\right)\right)}
$$

Discount rate beta:

$$
\beta_{i, D R}=\frac{\operatorname{cov}\left(r_{i, t},-\eta_{D R}\right)}{\operatorname{var}\left(r_{M, t}-E_{t-1}\left(r_{M, t}\right)\right)}
$$

where cov and var denote sample covariances and variances.

The cashflow component is abbreviated with $\eta_{C F}$, the discount rate news component with $\eta_{D R}, r_{i, t}$ denotes the individual value or growth stock excess return and $\mathrm{r}_{\mathrm{M}, \mathrm{t}}-\mathrm{E}_{\mathrm{t}-1}\left(\mathrm{r}_{\mathrm{M}, \mathrm{t}}\right)$ represents the unexpected market return. The discount rate beta is here defined as the covariance of a stock return with lower than expected discount rates. 


\begin{tabular}{|c|c|c|c|c|}
\hline \multicolumn{5}{|c|}{ Germany } \\
\hline & $\lambda_{R^{M}}$ & $R^{2}$ & mspe & Mape \\
\hline $\begin{array}{c}\text { Sharpe-Lintner } \\
\text { CAPM }\end{array}$ & $\begin{array}{l}0.65 \\
(0.43)\end{array}$ & 0.01 & 0.59 & 0.66 \\
\hline \multicolumn{5}{|c|}{ Belgium } \\
\hline & $\lambda_{R^{M}}$ & $R^{2}$ & mspe & Mape \\
\hline $\begin{array}{c}\text { Sharpe-Lintner } \\
\text { CAPM }\end{array}$ & $\begin{array}{l}3.50 \\
(1.67)\end{array}$ & 0.36 & 0.30 & 0.46 \\
\hline \multicolumn{5}{|c|}{ France } \\
\hline & $\lambda_{R^{M}}$ & $R^{2}$ & mspe & Mape \\
\hline $\begin{array}{c}\text { Sharpe-Lintner } \\
\text { CAPM }\end{array}$ & $\begin{array}{l}0.33 \\
(0.21)\end{array}$ & 0.01 & 0.46 & 0.58 \\
\hline \multicolumn{5}{|c|}{ Italy } \\
\hline & $\lambda_{R^{M}}$ & $R^{2}$ & mspe & Mape \\
\hline $\begin{array}{l}\text { Sharpe-Lintner } \\
\text { CAPM }\end{array}$ & $\begin{array}{l}0.91 \\
(-0.59)\end{array}$ & 0.08 & 0.43 & 0.54 \\
\hline \multicolumn{5}{|c|}{ Netherlands } \\
\hline & $\lambda_{R^{M}}$ & $R^{2}$ & mspe & Mape \\
\hline $\begin{array}{c}\text { Sharpe-Lintner } \\
\text { CAPM }\end{array}$ & $1_{(0.87)}^{1.77}$ & 0.10 & 0.42 & 0.50 \\
\hline \multicolumn{5}{|c|}{ Spain } \\
\hline & $\lambda_{R^{M}}$ & $R^{2}$ & mspe & Mape \\
\hline $\begin{array}{c}\text { Sharpe-Lintner } \\
\text { CAPM }\end{array}$ & -1.57 & 0.18 & 0.38 & 0.52 \\
\hline \multicolumn{5}{|c|}{ Switzerland } \\
\hline & $\lambda_{R^{M}}$ & $R^{2}$ & mspe & Mape \\
\hline $\begin{array}{l}\text { Sharpe-Lintner } \\
\text { CAPM }\end{array}$ & $\begin{array}{l}0.56 \\
(0.29)\end{array}$ & 0.01 & 0.46 & 0.57 \\
\hline
\end{tabular}

Notes: This table presents results from cross-sectional Fama-MacBeth regressions (Fama and MacBeth, 1973) for national CAPMs when confronted with value and growth stock returns of Berlgium, France, Germany, Italy, the Netherlands, Spain and Switzerland. $R^{2}$ is the cross-sectional $R^{2}$ used in Jagannathan and Wang (1996). The mean absolute (mape) and mean squared pricing errors (mspe) are reported in percentage points per quarter. The sample spans the period from 1975Q1 to 2005Q4. 


\begin{tabular}{|c|c|c|c|c|c|}
\hline \multicolumn{6}{|c|}{ Germany } \\
\hline & $\lambda_{N C F}$ & $\lambda_{N D R}$ & $R^{2}$ & mspe & Mape \\
\hline $\begin{array}{c}\text { Two-beta } \\
\text { CAPM }\end{array}$ & $\begin{array}{l}2.35 \\
(1.35)\end{array}$ & $\begin{array}{c}-8.78 \\
(-2.03)\end{array}$ & 0.48 & 0.31 & 0.42 \\
\hline \multicolumn{6}{|c|}{ Belgium } \\
\hline & $\lambda_{N C F}$ & $\lambda_{N D R}$ & $R^{2}$ & mspe & Mape \\
\hline $\begin{array}{l}\text { Two-beta } \\
\text { CAPM }\end{array}$ & $\begin{array}{l}2.87 \\
(1.76)\end{array}$ & $\frac{-2.80}{(-0.60)}$ & 0.53 & 0.22 & 0.39 \\
\hline \multicolumn{6}{|c|}{ France } \\
\hline & $\lambda_{N C F}$ & $\lambda_{N D R}$ & $R^{2}$ & mspe & Mape \\
\hline $\begin{array}{c}\text { Two-beta } \\
\text { CAPM }\end{array}$ & $\begin{array}{l}2.34 \\
(1.45)\end{array}$ & $\begin{array}{c}-7.59 \\
(-2.06)\end{array}$ & 0.54 & 0.21 & 0.38 \\
\hline \multicolumn{6}{|c|}{ Italy } \\
\hline & $\lambda_{N C F}$ & $\lambda_{N D R}$ & $R^{2}$ & mspe & Mape \\
\hline $\begin{array}{c}\text { Two-beta } \\
\text { CAPM }\end{array}$ & $\underset{(0.05)}{0.10}$ & $-{ }_{(-1.48)}^{12.29}$ & 0.28 & 0.33 & 0.51 \\
\hline \multicolumn{6}{|c|}{ Netherlands } \\
\hline & $\lambda_{N C F}$ & $\lambda_{N D R}$ & $R^{2}$ & mspe & Mape \\
\hline $\begin{array}{c}\text { Two-beta } \\
\text { CAPM }\end{array}$ & $\begin{array}{l}4.21 \\
(2.11)\end{array}$ & $\begin{array}{c}-3.97 \\
(-1.44)\end{array}$ & 0.62 & 0.18 & 0.35 \\
\hline \multicolumn{6}{|c|}{ Spain } \\
\hline & $\lambda_{N C F}$ & $\lambda_{N D R}$ & $R^{2}$ & mspe & Mape \\
\hline $\begin{array}{c}\text { Two-beta } \\
\text { CAPM }\end{array}$ & $\begin{array}{l}0.51 \\
(0.25)\end{array}$ & $\underset{(-2.44)}{-18.74}$ & 0.66 & 0.20 & 0.36 \\
\hline \multicolumn{6}{|c|}{ Switzerland } \\
\hline & $\lambda_{N C F}$ & $\lambda_{N D R}$ & $R^{2}$ & mspe & Mape \\
\hline $\begin{array}{l}\text { Two-beta } \\
\text { CAPM }\end{array}$ & $\begin{array}{l}1.76 \\
(1.09)\end{array}$ & $\begin{array}{c}-7.13 \\
(-1.99)\end{array}$ & 0.58 & 0.20 & 0.38 \\
\hline
\end{tabular}

Notes: This table presents results from cross-sectional Fama-MacBeth regressions (Fama and MacBeth, 1973) for two-beta versions of national CAPMs when confronted with value and growth stock returns of Belgium, France, Germany, Italy, the Netherlands, Spain and Switzerland. $R^{2}$ is the cross-sectional $R^{2}$ used in Jagannathan and Wang (1996). The mean absolute (mape) and mean squared pricing errors (mspe) are reported in percentage points per quarter. The sample spans the period from 1975Q1 to 2005Q4. 


\section{Figures}

Figures 1. to7: Average excess returns on value and growth portfolios relative to the ratio of cashflow and discount rate betas with respect to the national market returns.

Figure 1: Belgium

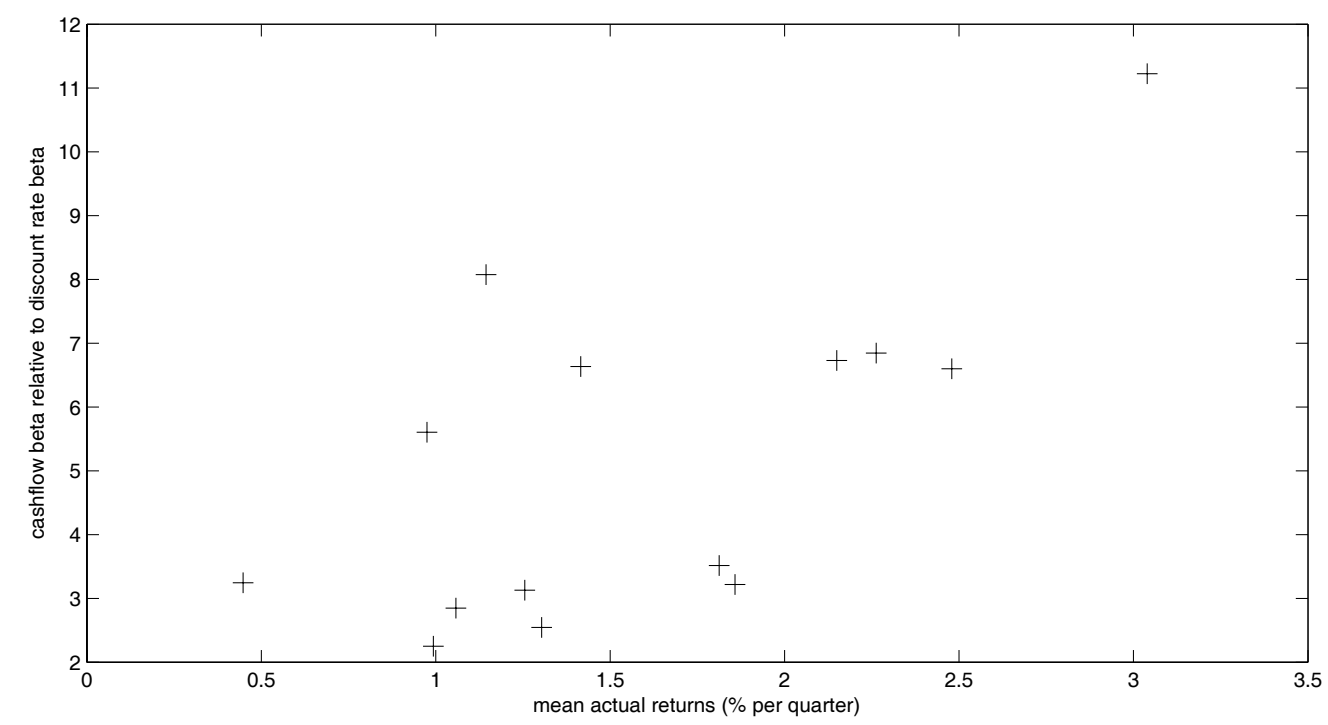

Figure 2: France

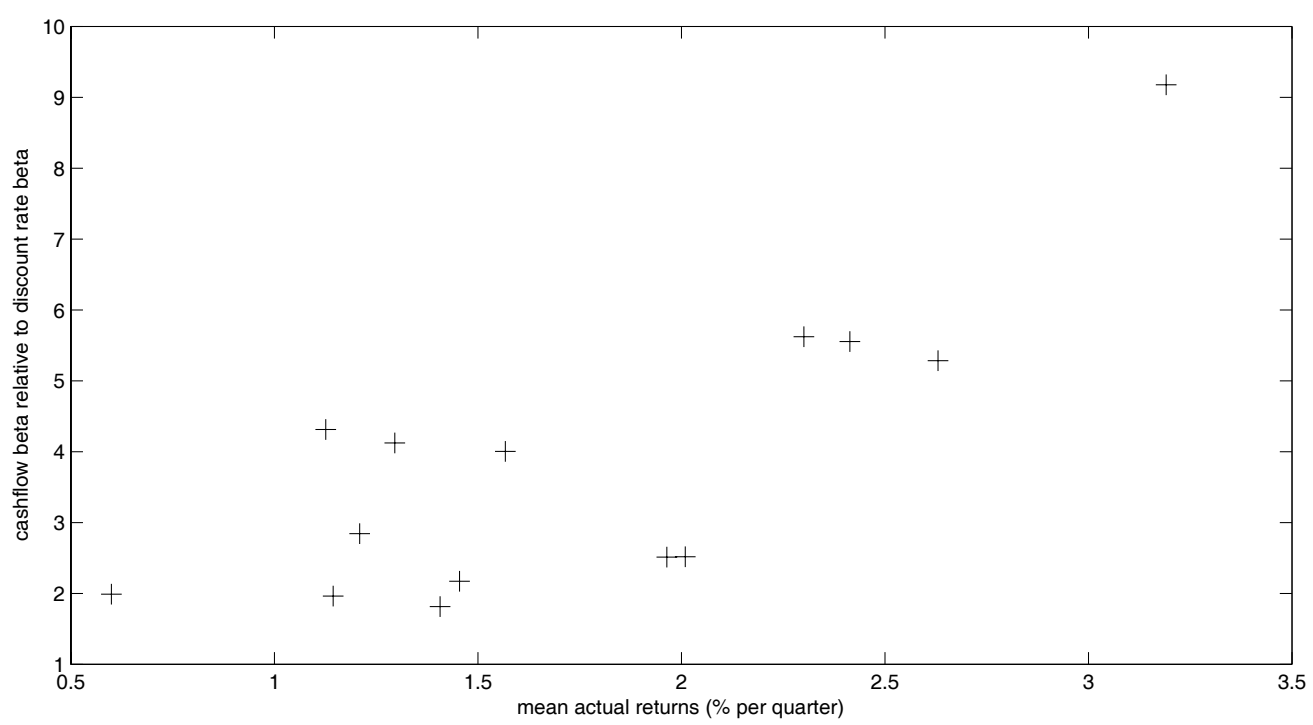


Figure 3: Germany

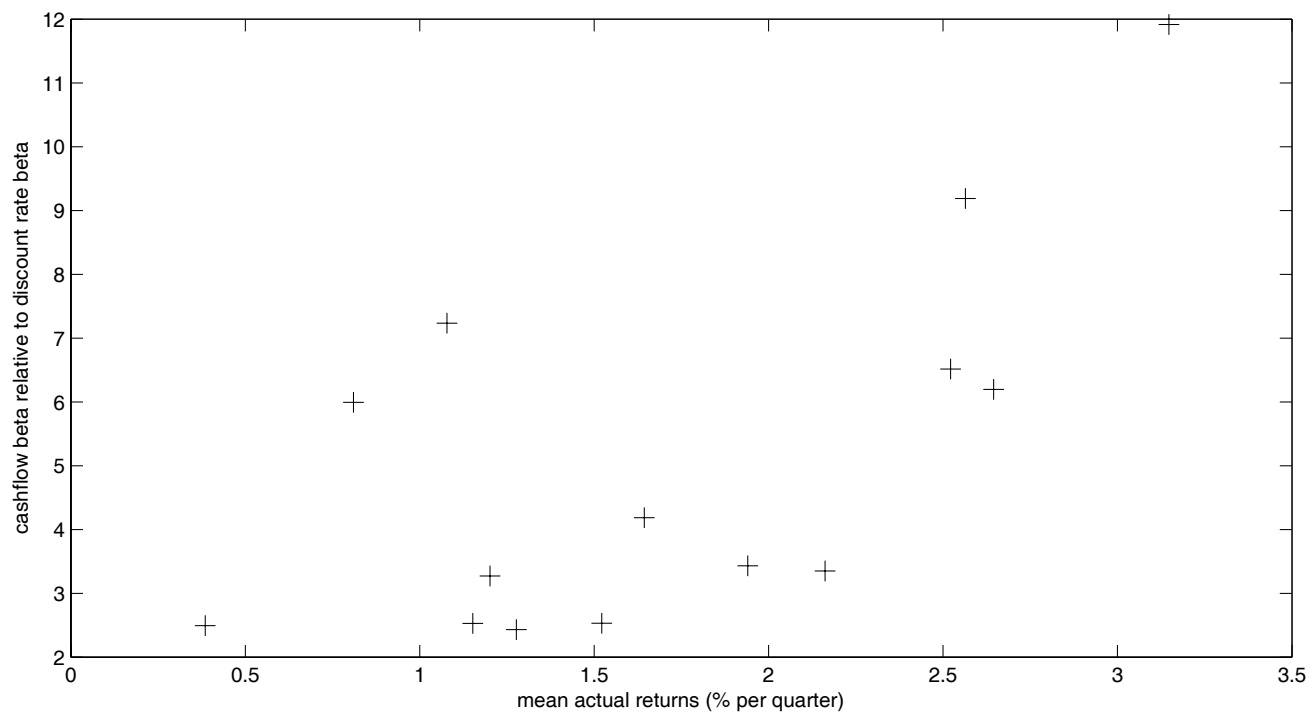

Figure 4: Italy

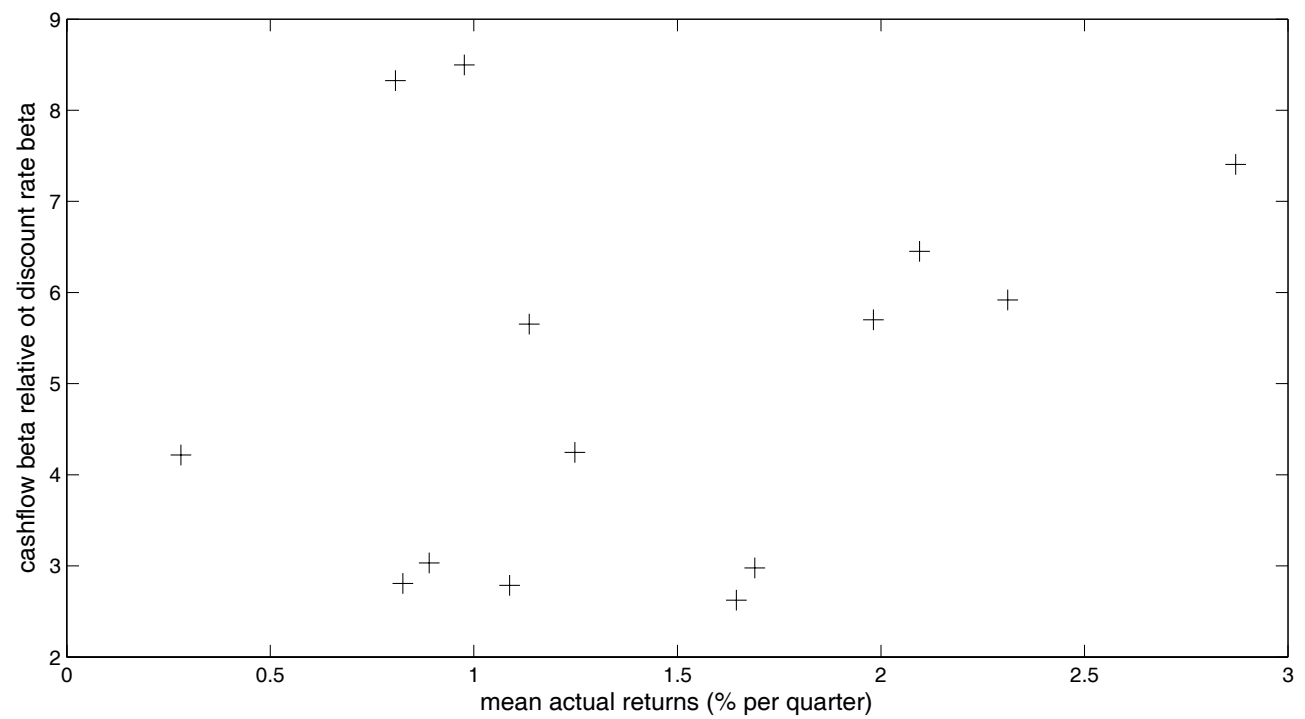


Figure 5: Netherlands

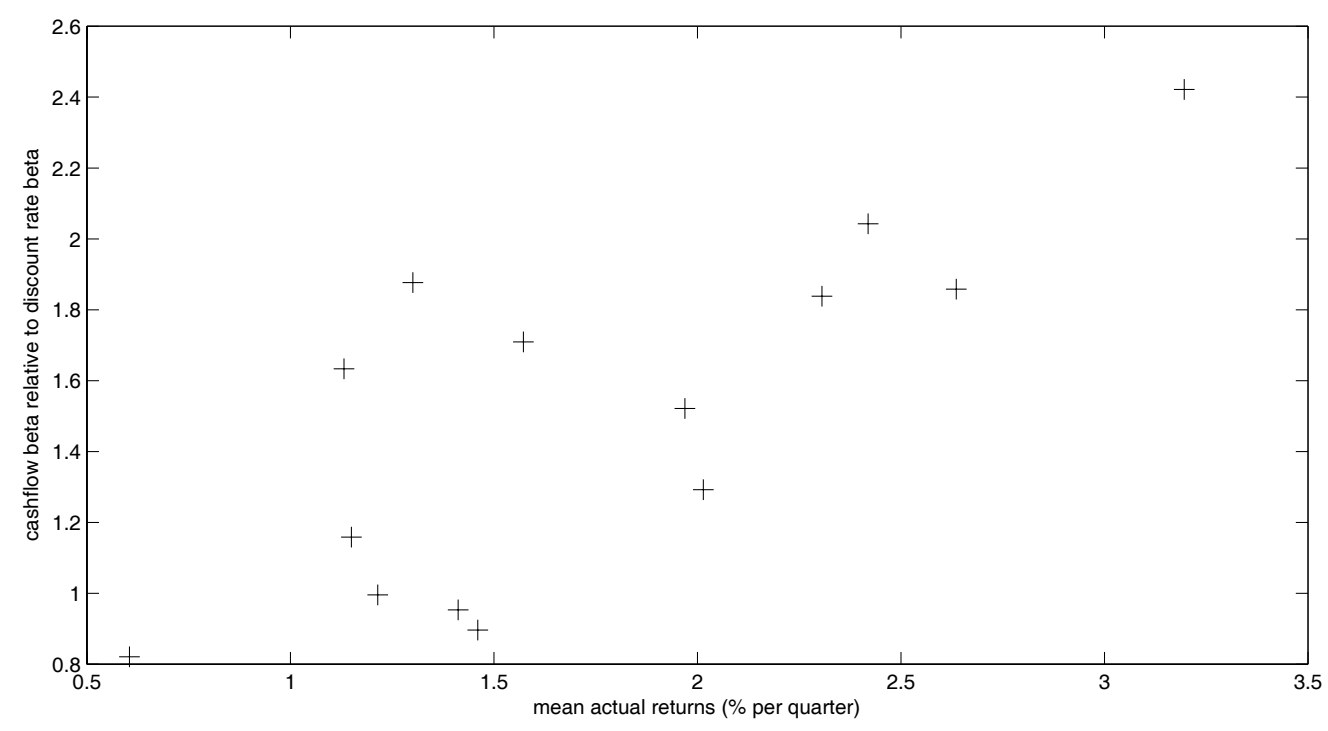

Figure 6: Spain

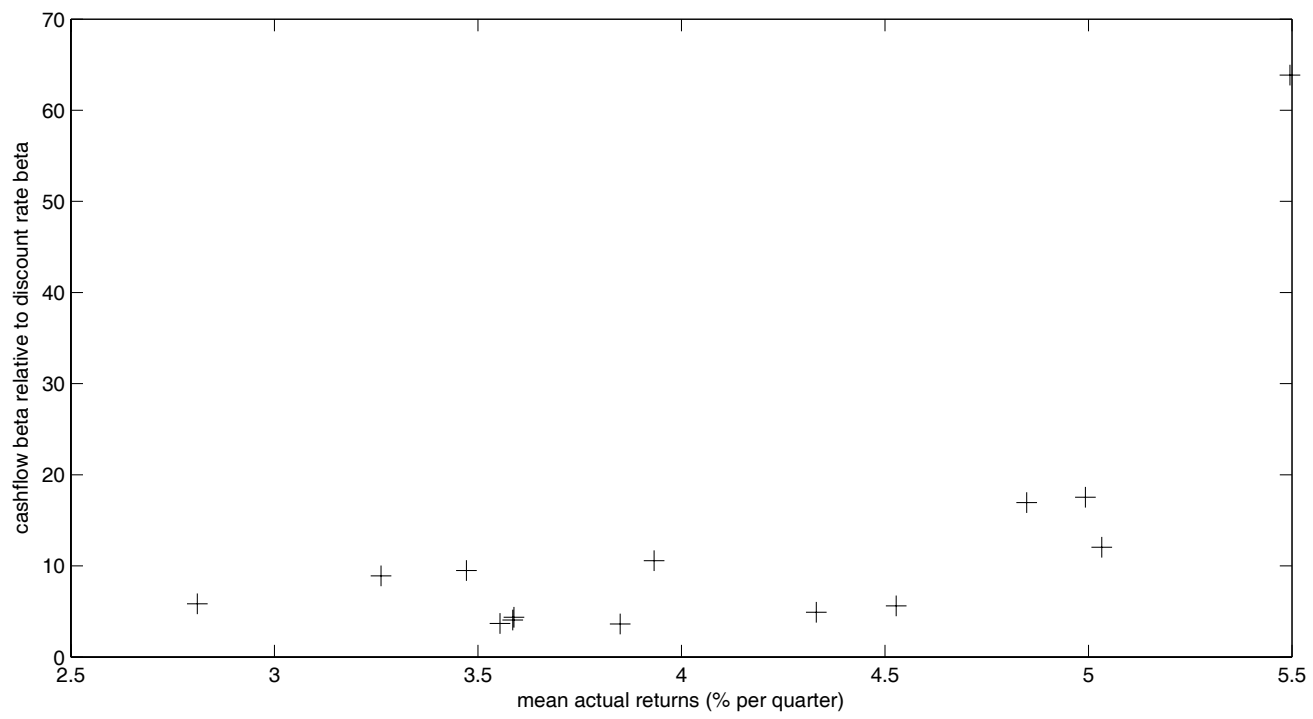


Figure 7: Switzerland

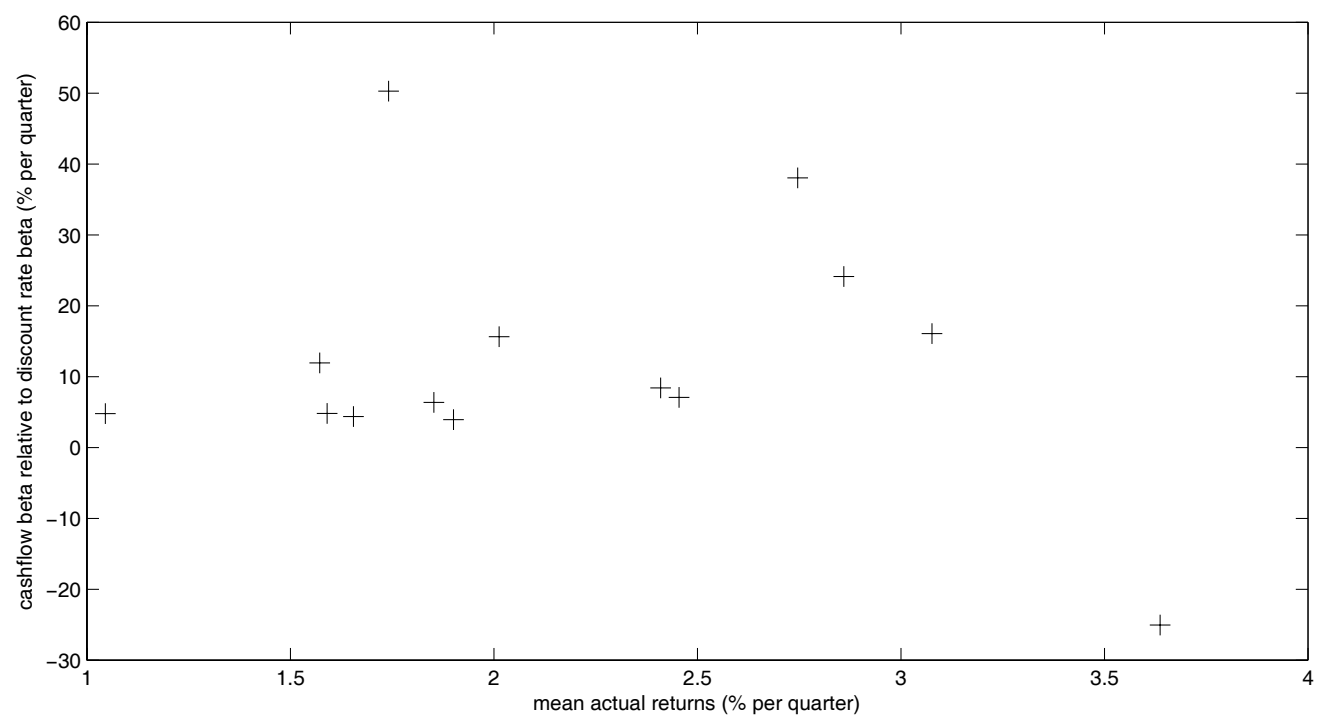

Figure 8: Average returns (horizontal axis)

versus German discount rate betas (vertical axis)

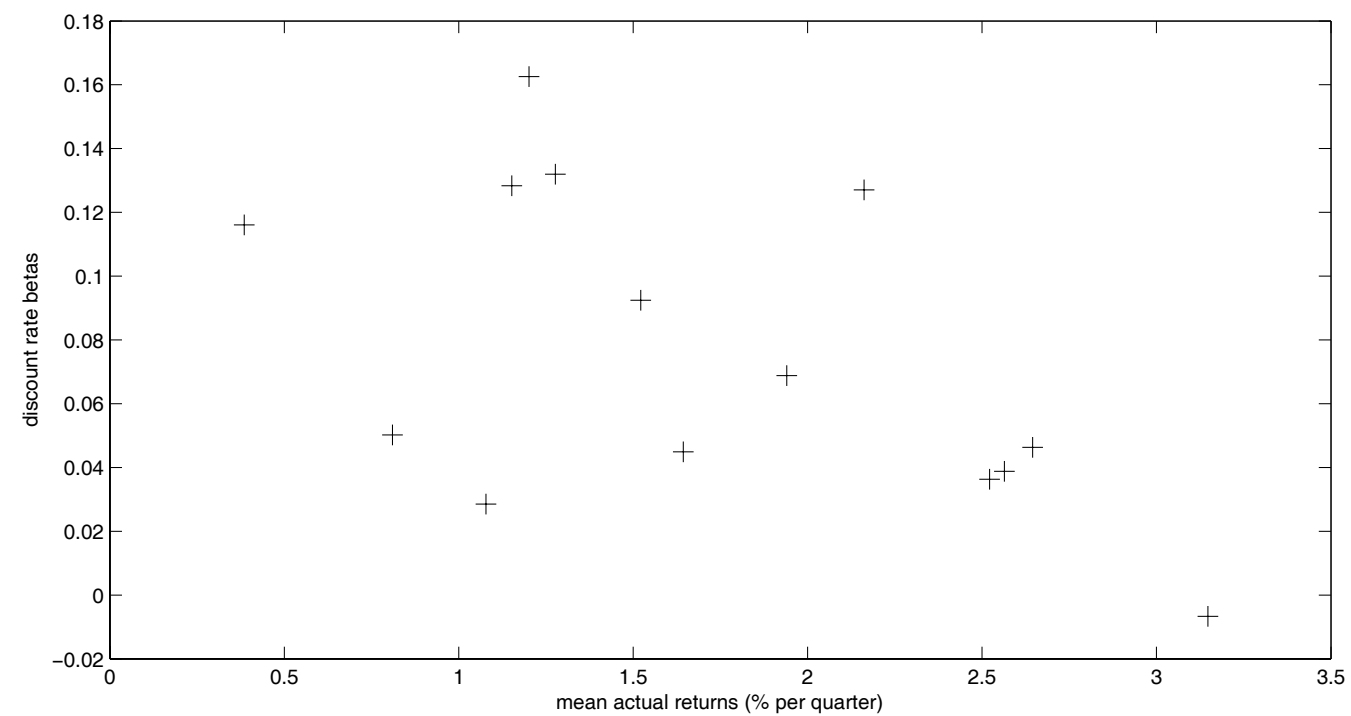


Figure 9: Average returns (horizontal axis)

versus Dutch cashflow betas (vertical axis)

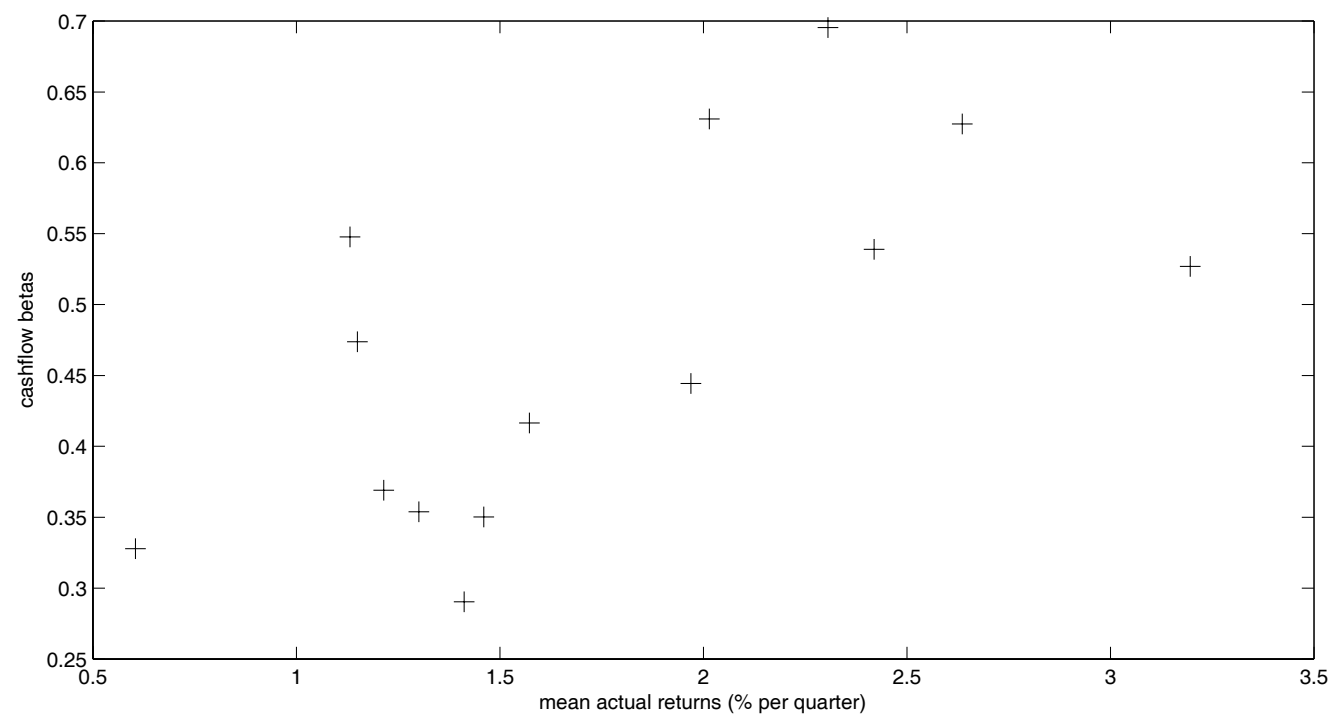

